\title{
nature
}

11 December 2003 Volume 426 Issue no 6967

\section{Lunar dreams, again}

There are rumblings from the White House about a grandiose vision for human space flight, ahead of President Bush's re-election campaign. If precedent is anything to go by, the results will be discomforting for NASA and for science.

A merican presidents seeking re-election are inclined to look for 'big ideas' that will re-invigorate their image with the public. Judging by the Washington rumour mill, the current president is no exception. According to several reliable sources, the Bush administration is considering a grand foray into human space flight, perhaps a return to the Moon. It's doubtful that a bold Kennedy-esque declaration is in the works, but history suggests that this is likely to be a bad way to reach for the stars.

The space shuttle and space station were each approved by presidents (Richard Nixon and Ronald Reagan) who faced re-election and the need to keep NASA busy after a big project (Apollo and the shuttle, respectively). Both conditions apply today, combined with an additional pressure: the Columbia accident has forced the Bush White House to make important decisions on the future of human space flight.

Left to his own devices, Bush would no doubt have avoided the subject. He showed little interest in space before becoming president, managing, for example, not to visit the Johnson Space Center in Houston during six years as governor of Texas. If his only motive now is to appear visionary in an election year, or to create employment for astronauts, NASA and the American people should say 'thanks, but no thanks'.

The space station, the last big presidential space initiative, is exhibit A for what can go wrong. Political and financial support for the project has always been lukewarm, which largely explains why Reagan's plan to complete the project "within a decade" has taken twice as long. Meanwhile, the station's rationale has shifted so many times that its purpose is uncertain even as it nears completion.

There is a case to be made for returning to the Moon. Planetary scientists have ranked a robotic lunar sample return high on their list of desirable missions. If field geologists are someday sent to Mars, the Moon might make a good proving ground. But could they practice on Earth instead? Can robots do the work just as well? Are lunar observatories preferable to orbiting telescopes? Will the US public be inspired by a trip that astronauts took 30 years ago? And would a near-Earth asteroid make a more compelling destination? These matters should be debated thoroughly and honestly before astronauts charge off to the Moon.

Perhaps a more fundamental question is whether NASA should lead that charge. The agency has shown a disturbing resistance to new ideas, and its technical expertise has been eroded in key areas. Sending astronauts to the Moon requires significant, sustained investment - not just to buy hardware, but to attract the kind of engineering talent that flocked to the Apollo programme in the 1960s.

What the space agency needs most right now is a vision that aligns with its budget. The Bush administration's plan may emphasize the contribution of private or other sources of funds, but in the end these funds won't amount to much. So the federal budget proposal announced at the beginning of February will be the best indicator of whether any space-exploration initiative is serious or not.

NASA administrator Sean O'Keefe has been arguing for two years that his agency should develop space technologies without a specific destination such as the Moon or Mars in mind. That never seemed a good idea, just a formula for aimless tinkering. Despite the unfortunate precedents of the shuttle and the space station, the United States does need at least to consider the idea of an overarching goal for human space flight. But a grand mission without the resources to accomplish it would be a recipe for decline — and possibly disaster.

\section{A new home for molecular biologists}

\section{Celebrating a major relaunch of a Nature journal.}

A chronic gap in the spectrum of Nature research journals is now to be filled. Following the launch in 1992 of the first such journal, Nature Genetics, we have progressively served several key disciplines in biology with such community-oriented publications. They seem to have fulfilled their initial goals, with all of them achieving a healthy subscription base and most of them lying at the top of their respective categories for impact factor .

But for too long, one group has been left without such a journal: molecular biologists. That label does not do justice to the diversity of interests of those who study biological phenomena at the molecular level. But many of them will, we hope, be pleased to find a new outlet for their outstanding papers in a new title to be launched at the beginning of January: Nature Structural $\&$ Molecular Biology.

In developing this publication, it has been important to preserve the great strengths of its predecessor, Nature Structural Biology, which has had the highest impact factor in its category - the new journal will carry forward its impact factor of 11.8. As its title indicates, the new journal will continue to serve its traditional community by including in its scope papers whose main message is structural.

But as its launch issue will demonstrate, it will also publish a significant proportion of papers that have no structural component at all, but which fall within the general goal of understanding biological processes at a molecular and mechanistic level. The emphasis of the journal will be on in vitro studies. The scope will include processes in the cell nucleus: DNA replication, repair, recombination, transcription, RNA processing and chromatin structure and remodelling. It will also include molecular-level studies of translation, signal transduction and protein folding, processing and degradation (for a complete list, see www.nature.com/nsmb). Analysis beyond a single component in a process and of coupling between cellular processes will also be welcome.

The number of pages in the journal and the number of editors on its staff are both being increased to accommodate this significant extension of its scope. Any author who is interested in submitting a paper to Nature Structural \& Molecular Biology should visit http://www.nature.com/nsb/esubmission/index.html. 